\title{
SOCIO-ENVIRONMENTAL AND SUSTAINABILITY ASSESSMENT FOR TECHNOLOGY INNOVATIONS AT PECTENS PRODUCTION IN BRAZIL
}

\author{
Márcio Ricardo Costa dos Santos (I), Geraldo Stachetti Rodrigues (2)
}

\begin{abstract}
This study presents a practical impact assessment method for the adoption of technology innovations at Pectens In vitro Fertilization Laboratory in Rio de Janeiro State, Brazil.To fulfill the system framework requirements, focused on reproductive and productive enterprises, field visits and interview with the laboratory executive director were carried out. Considering the pectens production activities, 24 socio-environmental indicators were developed and the impact indices were automatically calculated by the system's spreadsheets. General performance index for the pectens reproduction activities indicated an important contribution of technological innovations for the sustainable production of the In vitro Fertilization Laboratory. The employed method was considered as appropriate for evaluations of sustainability at this agribusiness activity, dealing with indicators as tools in order to identify possible risks for negative impacts. Those indicators include aspects beyond those commonly presented by environmental impact assessments, and were capable to provide adequate management and sustainable development for the studied Organization.
\end{abstract}

Keywords: sustainability indicators, impact assessment, reproduction management, pectens production, sustainable development.

Faculdade de Veterinária da Universidade Federal Fluminense. Rua Vital Brasil Fo, 64. CEP 24230-340, Niterói, RJ - Brazil.

(I) Corresponding author.Telefax.: +55 21 2710-9048, E-mail: mrcosta@doutor.com.br

(2) Laboratório de Manejo Ambiental - Embrapa Meio Ambiente, Jaguariúna, São Paulo - Brazil. 


\section{Introduction}

Socio-Environmental and Sustainability Assessment for Technology Innovations at Pectens Production in Brazil

Applications of technologies contribute always more for global development; from the economic, social and environmental point of view, to produce more with respect to the living beings, and are becoming hard to observe. The enterprise productive activities demand attention for research and the application of environmental evaluation systems, before the magnifying of the use of biotechnology products, because of the gradual focus changing to the green chemistry, biofármacos and bioenergia.

Independently of the agribusiness branch, the certification and rastreability methods gain importance on this process, with the establishment of multiple or mutually exclusive objectives between the social agents. The application of different scales of space and secular measures in the delimitation of the impacts, and the use of not standardized criteria for evaluations are some of the problems which many times contribute for the failure of the studies on environmental impact of new used technologies (Andrioli \& Tellarini, 2000).

Among the possible alternatives to carry out assessments of socio-environmental performance of agribusiness activities, the use of ecological and social indicators of sustainability has been a method of choice (Girardin et al., 1999; Bisset, 2000; Santos, 2006). The indicators should be organized in impact assessment systems that may span increasing levels of complexity and goal requirements for the environmental management (Rodrigues et al., 2003; Payraudeau et al., 2004).

The Brazilian Agricultural Research Agency (Embrapa) has proposed a system for environmental impact assessment of agricultural technology innovations (Ambitec-Agro) for the appraisal of research projects and technology innovations in the institutional context of R\&D (Monteiro \& Rodrigues, 2006), and in attendance to a demand of the "Inter-American Institute for Cooperation on Agriculture - Cooperative Program for the Agricultural Technological Development of the South Cone" (IICA - PROCISUR). A derived impact assessment system organized toward eco-certification of agribusiness activities was presented in 2006 and applied with excellent results to the environmental assessment practice of the aquaculture activities in Rio de Janeiro State (Santos, 2006). Another similar platform from the Ambitec-Agro has been proposed recently, integrating all environmental and social indicators, to implement the natural resources and biodiversity management in Uruguay, known as Responsible Production Project (Rodrigues \& Viñas, 2007).
The present paper worked out a sustainability evaluation system of best pectens production practices and its applications as a project appraisal for the technology innovation management methodology in the Pectens In vitro Fertilization Laboratory, to attend the Illa Grande Bay Marine Farming Program from the Institute for Eco-Development of the Ilha Grande Bay in Rio de Janeiro State. The System comprises a set of weighing matrices organized for the integrated assessment of socio-environmental indicators, including modules focused on the environmental impact assessment of pectens production, or similar agribusiness activities, with a specific module for social impact assessment. The calculated impact indices facilitate to making socio-environmentally sound decision and allow the delineation of recommendations for performance improvements, as well as selection of best cases for benchmarking purposes.

\section{Method}

This study presents a practical impact assessment method for the adoption of technology innovations in the Pectens In vitro Fertilization Laboratory (FIV-Lab) from the Institute for EcoDevelopment of the Ilha Grande Bay (IEDBIG), at Jacuacanga, Angra dos Reis district, Rio de Janeiro State, Brazil.

To fulfill the system framework requirements, focused on reproductive and productive enterprises, field visits and interviews supported by a structured questionnaire, with the laboratory executive director and farmers were carried out. The indicators related to soil and water quality were obtained by laboratory analysis at UFF, and the other related to historical and administrative knowledge of the director and farmers were obtained by interviews.

The sustainability evaluation system of best pectens production practices (Best-SES) consists of a 24 integrated indicators set (Figure I), spanning two dimensions namely landscape ecology and socio-environmental quality. These dimensions are integrated with seven essential aspects to encompass the FIV-Lab and the productive sea scallops, known as "Coquilles Saint Jacques" (Nodipecten nodosus, Linnaeus I758) marine farms, within the local environmental market settings.

The indicators weighting matrices are constructed in a MSExcel ${ }^{\circledR}$ platform to translate variables and attributes into environmental impact indices, expressed graphically and related to a utility function of environmental performance benchmarks, derived from sensitivity and probability tests, case-by-case for each indicator. The Best-SES was formulated to evaluate the sustainability indicators, considering its benchmark compliance 


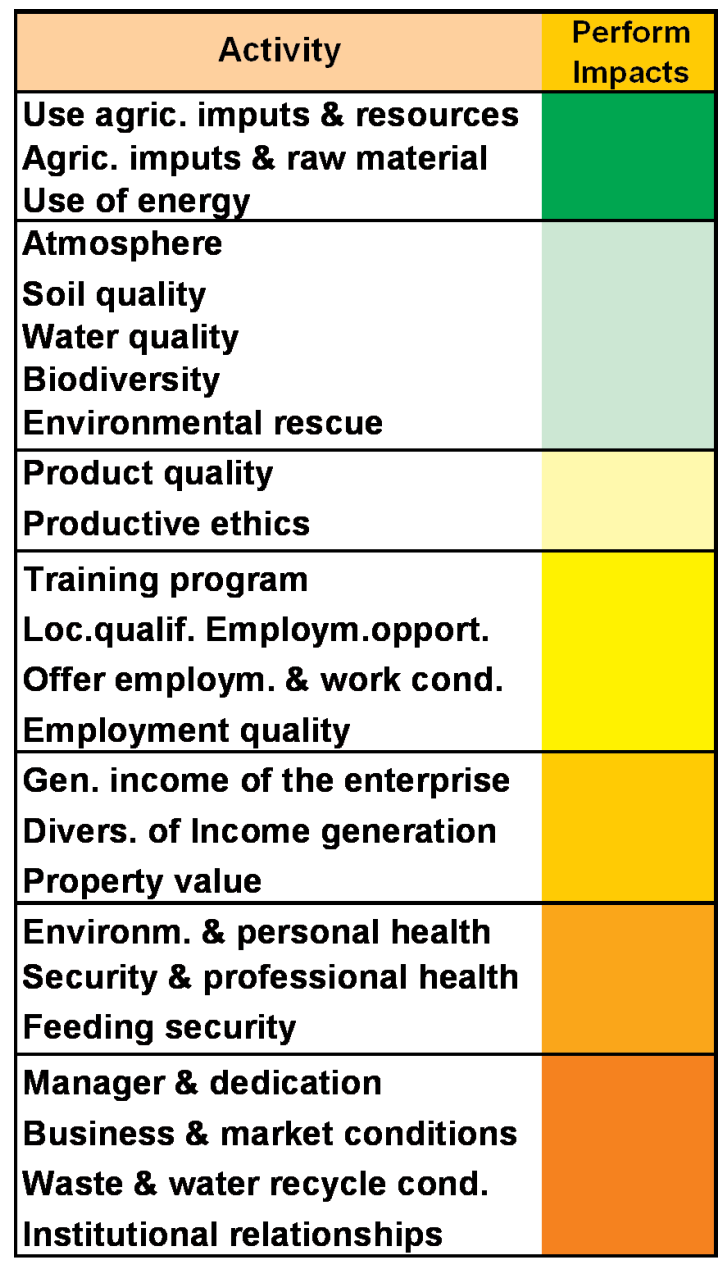

Figure I: Indicators set for the Eco-certification of rural activities evaluation system. Data based on PROCISUR (2006) and Santos (2006).

values, validated in contrasting situations representative of the establishments addressed spectrum, since the implantation of the technological innovations (2004) until the applied Best-SES (2006), according to the previous methodology presented by the authors (Rodrigues et al, 2006; Santos, 2006).

\section{Results}

The system's spreadsheets automatically calculated impact indices, in a scale ranging between \pm 15 , for 24 indicators from seven essential aspects, were as follows: Use of Inputs and Resources (-2.09), Environmental Quality (3.54), Costumer Respect (5.05), Employment (4.40), Revenue (2.17), Health (3.63), and Management and Administration (1.02). The general socioenvironmental performance index (5.04) for the pectens production activities indicated an important contribution of technological innovations for the sustainability of Pectens FIV-
Lab production. These results (Figure 2) show the good performance of the proposed system for the evaluation of technology management, agribusiness activities, regional development, and for sustainability performance assessment for pectens production.

\section{Discussion}

While environmental conservation and social responsibility issues gain increasing importance in the development agendas at all institutional levels, it becomes necessary to select, adapt, transfer, and assess sustainable environmental management and best production practices (Barnthouse et al., 1998). Especial reference to this managerial movement is warranted when agribusiness activities are regarded, because of the spatial scale and bulk of natural and human resources encompassed worldwide by agriculture (Pimentel et al., 1992). 


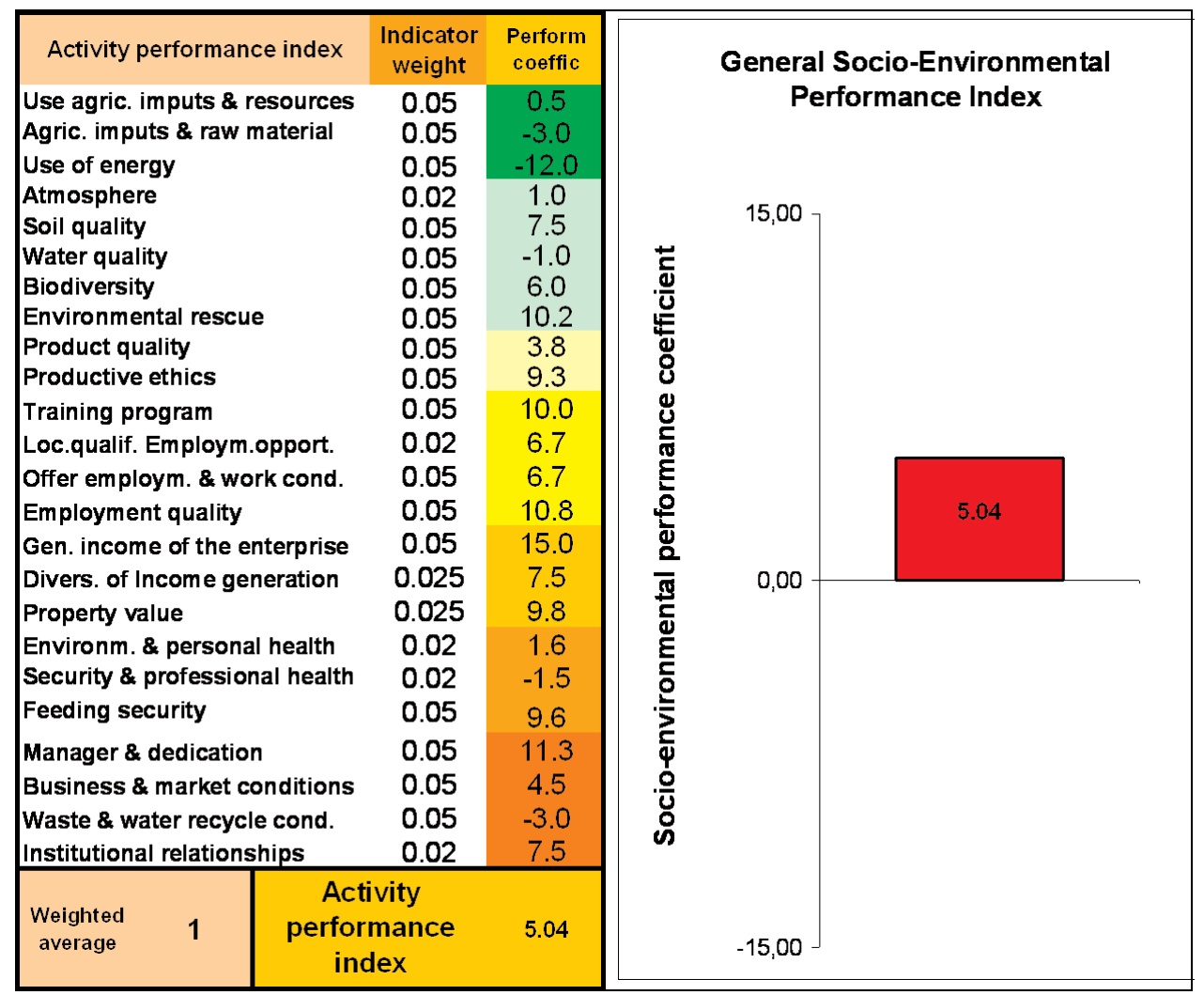

Figure 2: Results obtained with the Socio-Environmental and Sustainability Assessment for Technology Innovations at Pectens Production in Brazil, for general socio-environmental indicators and its performance index for the FIV-Lab activities.

In order to bring a practical reach to this sustainable development objective, society should value and recompense farmers and producers who adequately manage their environment and resources, both as an incentive towards sustainability and as repayment for environmental and social services rendered (Viglizzo et al., 200I).

In effect, a multi-attribute EIA system for agribusiness activities' environmental management, integrating dimensions related to landscape ecology, environmental quality, sociocultural values, economic values, and management values should be applied. It is currently under extensive field application, like this work, with contribution to the stepwise process of sustainable agricultural technology development and appraisal (Rodrigues \& Viñas, 2007).

The IEDBIG established the goal of combating poverty as its line of strategy within the context of its social responsibility, and its main objective is to encourage raising endangered species in marine farms, while preserving traditional fishing methods. The Ilha Grande Bay Marine-Farming Program, known as POMAR, promotes the creation of marine farms and work to- wards the principle of sustainability and autonomy for low-income fishermen communities based in Angra dos Reis, State of Rio de Janeiro - Brazil (Santos \& Zaganelli, 2007).

Considering the pectens production and the marine farms activities, 24 socio-environmental indicators were developed and the impact indices were automatically calculated by the system's spreadsheets. General performance index for the pectens reproduction activities indicated an important contribution of technological innovations for the sustainable production of the FIV-Lab. The employed method was considered as appropriate for evaluations of sustainability at this agribusiness activity, dealing with indicators as tools in order to identify possible risks for negative impacts. Those indicators include aspects beyond those commonly presented by environmental impact assessments (Girardin et al., 1999; Bisset, 2000, Rodrigues et al., 2003), and were capable to provide adequate management and sustainable development for the studied Organization.

The present paper revised the impact assessment systems, discusses their application for the pectens production with technological innovation management, and aim to the conclusions: 
.The main contributions were to improve the understanding of producers and researchers alike, about the social and environmental implications of the adoption of agribusiness technology innovation, and to introduce socio-environmental impact assessments at an operational level, facilitating the grasp of interactions between technology adoption and the sustainable development of aquaculture.

- The acceptance of simpler assessment system is an important step toward more complex methods that require a stronger analytical basis and involve a more complex theoretical foundation.

- The Best SES consists of a practical EIA system for technology innovations, ready for field application through interviews, with directed survey at the FIV-Lab, marine farms and manager responsible for the agribusiness activity, modified by the adoption of the studied technology.

- The system relies on a computational platform readily available and easily applicable at low cost, and facilitates the storage and communication of information regarding environmental impacts.

- The computational structure for the system is simple and transparent, unveiling to the user all operations performed with the data. Also, while fairly standardized relative to measurements, the system is malleable, allowing the user to adapt for specific use situations, by changing the weighing factors of indicators and components when appropriate.

\section{Acknowledgements}

The authors thank the Executive Director of IEDBIG, Engineer José Luiz Zaganelli, for the contributions to this work and previous cooperation. This study was supported by the Pomar Project/IEDBIG, Angra dos Reis, Rio de Janeiro - Brazil.

\section{References}

ANDRIOLI, M.; Tellarini,V. 2000. Farm sustainability evaluation: methodology and practice. Agriculture, Ecosystems and Environment, 77: 43-52.

BARNTHOUSE, L; Biddinger, G; Cooper,W; Fava, J; Gillett, J; HoIland, M;Yosie, T (Eds). 1998. Sustainable Environmental Management. Pellston: Society of Environmental Toxicology and Chemistry, Pellston Series Workshops. 102 p.

BISSET, R. 2000. Methods for environmental impact assessment: a selective survey with case studies, a methodology and terminology of sustainable assessment and its perspectivrs for rural planning.Agriculture, Ecosystems and Environment,Amsterdam, 77:29-4I.

GIRARDIN, P; Bockstaller, C; van der Werf, H. 1999. Indicators: tools to evaluate the environmental impacts of farming systems. Journal of Sustainable Agriculture, 13(4): 5-2 I.

MONTEIRO, R.C; Rodrigues, G.S. 2006.A system of integrated indicators for sócio-environmental assessment and eco-certification in agriculture - Ambitec-Agro. Journal of Technology Management and Innovation, I (3):47-59.

PAYRADEAU, S; Hayo, MG;Van der Werf, H. 2004.Environmental impact assessment for a farming region: a review of methods. Agriculture Ecosysistem and Environment. 107: I- 19.

PIMENTEL, D; Stachow, U; Takacs, DA; Brubaker, HW; Dumas, AR; Meaney, Jj; O'Neil, JAS; Onsi, DE; Corzilius, DB. 1992. Conserving biological diversity in agricultural / forestry systems. BioScience. 42: 354-362.

PROCISUR (PTR). 2006. Regional Technological Platform. (Available at: < http://www.procisur.org.uy/online/sustentabilidad_inicial.asp >access on 02.01.2006)

RODRIGUES, GS, Campanhola C, Kitamura PC. 2003. An environmental impact assessment system for agricultural R\&D. Environmental Impact Assessment Review. 23(2): 219-244.

RODRIGUES, G.S.; Viñas, A.M. 2007. An environmental impact assessment system for responsible rural production in Uruguay. Journal of Technology Management and Innovation, 2(I):42-54.

RODRIGUES, GS; Buschinelli, CC de A; Rodrigues, IA; Monteiro, RC;Viglizzo, E. 2006. Sistema base para eco-certificação de atividades rurais. Jaguariúna: Embrapa Meio Ambiente (Boletim de Pesquisa e Desenvolvimento 37). 40 p. (Available at: < http://www.cnpma.embrapa.br/public pdf2 I.php3?tipo=bo\&id=75 $>$ access on 04.28.2008).

VIGLIZZO, EF; Lértora, FA; Pordomingo, AJ; Bernardos, J; Roberto, ZE; Del Valle, H. 200 I. Ecological lessons and applications from one century of low external-input farming in the pampas of Argentina. Agriculture, Ecosystems \& Environment. 81: 65-8I.

SANTOS, M.R.C. 2006. Gestão da Inovação Tecnológica e do Desempenho Sustentável das Atividades em Laboratório de Fecundação In vitro e Larvicultura de Vieiras (Nodipecten nodosus). Monografia (MBA em Gestão de Negócios Sustentáveis), Universidade Federal Fluminense - Latec, Niterói: 2006. 95p. 
SANTOS, M.R.C.; ZAGANELLI, J.L. Socio-Environmental and sustainability assessment for regional development in Angra dos Reis, RJ - Brazil. Book of Abstracts. p.83. (Available at: $<$ http://www.uni-tuebingen.de/deutsch-brasilianischessymposium/Symp2007-ed2.pdf $>$ access on 04.29.2008).

\section{About the Authors:}

Márcio Ricardo Costa dos Santos was born in Niterói, Rio de Janeiro State, Brazil, in April 18, 1950. He received his Doctor Veterinary Medicine. degree from the Universidade Federal Fluminense (UFF) in 1972, earned his Medical Residency from the Cornell University Veterinary College in 1976, and the Master of Science in 1977. He went to Germany and earned his Ph.D. in Biotechnology of Reproduction at the Ludwigs Maximilians Universität in 1986 and Post-Doc at the Technische Universität München in 1988. Dr. Santos joined the Department of Pathology and Clinics at UFF in 1976 as an Assistant Professor of Physiopathology of Reproduction, and was promoted to Associate Professor in 1986. Later on He spent two years 200406 at the LATEC/UFF on a MBA Program in Management of Sustainable Business, where he dedicated his attention to environmental management and agribusiness activities eco-certification. He served as Professor of Physiopathology of Reproduction from 1989 to 2003, and now is the Head of Special Projects Office from PROEX/UFF.

Geraldo Stachetti Rodrigues was born in São Paulo, Brazil, in July 16, 1960. He received his B.Sc. degree in Ecology at Universidade Estadual Paulista (UNESP, Rio Claro) in 1982 and later on went to lecture Environmental Sciences at the prestigious School of Mines of Ouro Preto (Minas Gerais, Brazil). He entered the environmental research unit of the Brazilian Agricultural Research Agency (Embrapa) in 1987, and earned his Ph.D. in Ecology and Evolutionary Biology from Cornell University (Ithaca, NY, USA) in 1995. He spent the academic year of 200 I02 on a sabbatical at the Center for Environmental Policy of the University of Florida (Gainesville, USA) where he dedicated his attention to multi-attribute methods and emergy analysis applied to environmental impact assessment. He served as Head of Research and Development for Embrapa Environment from 2002 to 2005 and is now working on multi-scale environmental management and eco-certification of rural activities. 